\title{
İvesi Koyunlarının Et Kalitesini Değerlendirmede Temel Bileşenler Analizinin (PCA) Kullanılması
}

\author{
Yıldırım DEMİR*1, Nurinisa ESENBUĞA², Ömer Cevdet BİLGİN2 \\ 1Yüzüncü Yıl Üniversitesi, Van Meslek Yüksekokulu, Van \\ ${ }^{2}$ Atatürk Üniversitesi, Ziraat Fakültesi, Zootekni Bölümü, Erzurum
}

(Alınış / Received: 11.04.2016, Kabul / Accepted: 24.06.2016, Online Yayınlanma / Published Online: 22.07.2016)

\author{
Anahtar Kelimeler \\ Temel bileşen analizi (PCA), \\ Et kalitesi, \\ İvesi koyun
}

Özet: Bu çalışmada, İvesi koyunlarda et kalitesini belirlemek amacıyla ölçülen farklı özellikler, Temel Bileşenler Analiz (PCA) yöntemi kullanılarak bütüncül bir yaklaşımla ve görsel olarak değerlendirilmiștir. Yirmi beș baș 10 aylık yaştaki İvesi koyunun $m$. longissimusdorsi kasından et numuneleri alınmış ve et kalitesi üzerine etkili olduğu düşünülen onyedi değişken Temel Bileșenler Analizi yöntemi ile detaylı bir șekilde irdelenmiștir. Et kalitesinde gözlenen toplam varyansın önemli bir bölümünün fiziksel özelliklerden $\mathrm{pH}$; renk değerlerinden $\mathrm{L}^{*}$ ve $\mathrm{a}^{*}$; kimyasal özelliklerden kül, protein ve yağ; duyusal özelliklerden gevreklik, sululuk, flavor, genel kabul edebilirlik ve yutmadan önceki çiğneme sayısından kaynaklandığı görülmüștür. Sonuç olarak toplam varyansın \%68.91'lik kısmının ilk dört temel bileșen tarafından açılanmıș olduğu tespit edilmiştir.

\section{Use of Principal Component Analysis (PCA) to Evaluate Meat Quality of Awassi Sheep}

\section{Keywords}

Principal component

analysis (PCA),

Meat quality,

Awassi sheep

\begin{abstract}
In this study, various traits measured to determine meat quality of Awassi sheep were evaluated using Principal Components Analysis by a wholistic approach and visual presentation. Meat samples of $m$. longissimusdorsi muscles were taken from 25 Awassi sheep at approximately 10 months of age and 17 variables conjectured as effective on meat quality were examined in detail by means of Principal Components Analysis. Total variance observed on meat quality was mostly accounted by $\mathrm{pH}$ as a physical trait; $\mathrm{L}^{*}$ and $\mathrm{a}^{*}$ as colour traits; ash, protein, and fat as chemical traits; juiciness, flavour, overall acceptability, and number of chewing before swallow as sensorial traits. As a result, it was showed that $68.91 \%$ of the total variance was explained by the first four components.
\end{abstract}

\section{Giriş}

Kırmızı et tüketiminin sağlıklı ve dengeli beslenme üzerinde, sağlıklı ve dengeli beslenmenin ise insanların bedensel ve zihinsel faaliyetlerini daha iyi sürdürebilmesi üzerinde çok büyük bir etkisi bulunmaktadır. Bu nedenle son dönemlerde sadece et tüketimine olan talep değil aynı zamanda tüketicilerin kaliteli ete olan talepleri de artmıştır. Hayvanın ırkı, yaşı, cinsiyeti, bakım ve beslenme şartlarına ek olarak kesimden önce hayvanın kesimhaneye taşınma şekli, yeterince dinlendirilmiş olması, kesim şekli ve kesim sonrası süreç gibi birçok faktör et kalitesini etkilemektedir. Ayrıca karkas oldukça heterojen bir yapıya sahip olduğundan etin alındığı bölge de kalitesini önemli derecede etkilemektedir. Etin kalite özelliklerini tanımlamak amaciyla kimyasal, fiziksel ve duyusal muayene gibi çok farklı analizlere ihtiyaç duyulmaktadır. Anılan bu analizler sonucunda elde edilen çok sayıda veriyi istatistik olarak değerlendirmek amacıyla kullanılan klasik yöntemler her değişkene göre önemli bilgiler vermesine rağmen iki ya da daha fazla farklı özellik arasında bir ilişkinin varlığı hakkında gerçek bir bilgi sunmada yetersiz kalmakta ve homojen yapıya sahip örneklerin gruplandırılmasına da imkân vermemektedir [1]. Bu nedenle orijinal değişkenlerin daha kolay yorumlanabilmesini sağlamak amaciyla temel bileșenler analizi (PCA= Principal Component Analysis) gibi çok değişkenli istatistiksel yöntemlere ihtiyaç duyulmaktadır [2]. Temel bileşenler analizi, en eski ve en yaygın kullanılan çok değişkeli istatistik yöntemler arasında yer almaktadır. Bu fikir ilk kez Pearson tarafından ortaya atılmış [3] ve daha sonra çok sayıda verinin korelasyon yapısını eș zamanlı bir şekilde belirleyebilmek amacıyla Hotelling tarafindan 
bağımsız bir şekilde geliştirilmiştir [4]. Latent ilişkiler için yapılacak analizlerde, çok değişkeli analiz yöntemleri etkili sonuçlar elde edilmesini sağlamaktadır [5].

PCA çok değişkeli veri matrisinde değişkenler arası ilişkinin yönünü tanımlamaya ve bir grafik üzerinde bulguları sunmaya yarayan analiz yöntemidir. Temel bileşenler analizi olarak adlandırılan PCA bir veri kümesindeki orijinal değişkenleri aralarında korelasyon bulunmayan daha az sayıda yeni değişkenlere dönüștürür [6]. PCA yöntemi, ırklar arasında karkas ve et kalitesini karşılaștırmak, kesim öncesi ve sonrası uygulamaların et kalitesine etkisini daha detaylı bir biçimde ve görsel olarak değerlendirebilmek üzere yaygın bir şekilde kullanılmaktadır.

Karlsson karkas ve et kalitesi arasında önemli bir ilişki bulunduğunu göstererek, et kalitesini belirlemek amacıyla aralarında ilişkinin bulunduğu çok sayıda değişkenin mevcut olduğu durumda, çok fazla bilgi kaybı olmadan bu değişkenleri birbirinden bağımsız çok daha az sayıda değişkene indirgeme imkânı olduğunu belirtmiştir. Çalışmasında temel bileşenler analizini kullanarak domuzlarda et kalitesine ait korelasyonlu değişkenleri, basit bir şekilde orijinal değişkenlerin korelasyonsuz doğrusal fonksiyonlarına dönüştürülebileceğini göstermiştir [7]. Daha önce yapılmış bazı çalışmalarda et kalitesi üzerinde etkili değişkenlerin belirlenmesinde PCA kullanılmıştır. Laville, şarole ırkı boğa karkaslarını değerlendirmek amacıyla 76 morfolojik değişken ele almış ve toplam varyansın \%80'nini 10 temel bileşenle açıklayabilmiştir [8]. Genç boğaların et kalitesini değerlendirmek amacıyla 18 değişken ele alınmış ve toplam varyansın \%82.29'u 6 temel bileşenle açıklanmıştır [2]. Tavşanlarda et kalitesini değerlendirmek amacıyla 23 değişken ele alınmış ve toplam varyansın \%62'si 4 temel bileşenle açıklanmıştır [9]. Kuzularda et kalitesini değerlendirmek amacıyla 21 değişken ele alınmış toplam varyansın \%74.93'ü 8 temel bileşenle açıklanmıştır [6]. Holstein boğalarda et kalitesini değerlendirmek amacıyla 16 değişken ele alınmış ve toplam varyansın \%75.34'ü 5 temel bileşenle açıklanmıştır [1]. Bafra kuzularında et kalitesini değerlendirmek amaciyla 12 değişken ele alınmış ve toplam varyansın \%79.68'i 5 temel bileşenle açıklanmıştır [10].

Bu çalışmada, İvesi koyunlarına ait et numuneleri çeşitli kimyasal, fiziksel ve duyusal değerlendirmelere tabi tutularak, PCA ile ivesi koyunlarında et kalitesi üzerine etkili en önemli değişkenlerin belirlenmesi amaçlanmıştır.

\section{Materyal ve Metot}

Araștırmanın hayvan materyalini, Atatürk Üniversitesi Ziraat Fakültesi Araştırma ve Uygulama
İşletmesinde yetiştirilen 10 aylık yaşta 25 İvesi ırkı koyun oluşturmuştur. Hayvanların kesimini takip eden ilk 15 dakika içerisinde $\mathrm{pH}$ değerleri taze et yüzeyinden direkt probe ile ölçülmüştür (SCHOTT, Lab Star).

Kesimden sonra $\pm 4^{\circ} \mathrm{C}^{\prime}$ de yirmi dört saat dinlendirilen karkasların $m$. longissimusdorsi kasından örnekler alınmıştır. Renk değerleri L*(parlaklık), a* (kırmızılık) ve $b^{*}$ (sarllı) Aurand ve ark. [11] ve Rödel [12] tarafından bildirilen metotlara uygun olarak belirlenmiștir (CR-200, Minolta Co, Osaka, Japan). L*, $a^{*}$ ve $b^{*}$ değerleri üç boyutlu renk ölçümünü esas alan Uluslararası Aydınlatma Komisyonu CIELAB kriterlerine göre yapılmıştır. İlk renk değerleri numune yüzeyi kesildikten sonra alınmış ve bu ölçüm 0 saat olarak kabul edilmiştir. Duyusal ve kimyasal analizler için kullanılmak üzere homojen bir şekilde ikiye ayrllan kas örneklerinin bir bölümünde su, yağ, protein ve kül analizleri yapılmıştır [13]. Duyusal örnekler için ayrılan kas örnekleri plastik torbalar içerisine konularak $90^{\circ} \mathrm{C}$ 'de $\mathrm{ki}$ su banyosunda iç sıcaklıkları $70^{\circ} \mathrm{C}^{\prime}$ ye ulaşıncaya kadar pişirilmiştir. Pişirme randımanı, pişmiş ve pişmemiş et örneklerinin ağırlıklarının oranlanması yolu ile hesaplanmıştır. Pişmiş et örnekleri 1x1x1 cm boyutlarında kesilerek; gevreklik, sululuk, genel kabul edilebilirlik, lezzet yoğunluğu ve yutmadan önceki çiğneme sayısı gibi parametreler bakımından değerlendirilmek üzere panelistlere servis edilmiştir. Duyusal analizler için 9 puanlık hedonik değerlendirme sistemi ( $9=$ Çok gevrek, 1=Çok sert; $9=$ Çok sulu, $1=$ Çok kuru; $9=$ Çok yoğun lezzet, $1=$ Çok az lezzet yoğunluğu; 9=Çok yüksek oranda genel kabul edilebilirlik, 1=Çok düşük oranda genel kabul edilebilirlik) kullanılmıștır. Mekanik olarak gevreklik ölçümü, pişmiş ve $20^{\circ} \mathrm{C}^{\prime}$ ye kadar soğutulmuş et örneklerinin Warner Bratzler Shear (WBS) aletiyle değerlendirilmesi sonucunda yapılmıştır [14].

TBARS (Tiyobarbitürik asit) değerinin belirlenmesi Lemon [15] ve Kılıç ve Richards [16] tarafından bildirilen metotlara uygun olarak yapılmıştır. Kollajen miktarı ise Tauchman [17] tarafindan bildirilen metotlara uygun olarak belirlenmiștir.

\section{1. İstatistik analiz}

Temel Bileşenler Analizi (PCA) $p$ sayıdaki orijinal değişkeni, temel bileşenler olarak bilinen $k$ sayıdaki yeni değişkenlere dönüștürmek amaciyla kullanılmaktadır. Temel bileșenler, $p$ tane rastgele $X_{1}$, $X_{2}, \ldots, X_{\mathrm{p}}$ orijinal değişkenlerinin doğrusal bileşenidir. Buna göre temel bileșenlerin toplam sayısı orijinal değişkenlerin yani üzerinde çalışılan özelliklerin sayısına eşittir. Ancak analiz sonuçlarının yorumlanmasında genellikle sadece ilk iki ya da ilk üç temel bileşen dikkate alınmaktadır. Zira, orijinal değişkenlerdeki varyasyonun büyük bir kısmını açıklamak için çoğu zaman ilk iki temel bileşen yeterli olmaktadır. $\mathrm{Bu}$ da verinin önemli bir oranda 
özetlenmesine ve daha kolay yorumlanmasına olanak sağlamaktadır [1]. Ancak dikkate alınacak temel bileșen sayısını belirlenmenin en doğru yolu kümülatif varyansı \%67'den büyük yapan bileșenin referans alınmasıdır [18].

Her örnekte $p$ sayıda $X_{i}$ değişkenleri varsa, $Y_{i}$ temel bileşenleri,

$$
Y_{i}=a_{i 1} X_{1}+a_{i 2} X_{2}+a_{i 3} X_{3}+\cdots+a_{i p} X_{p}
$$

şeklinde ifade edilir. Burada $a_{i j}$ j. değişkenin i. temel bileşene ait ağırlığını göstermektedir. Temel bileşen ağırlıkları aşağıdaki koşulları sağlayacak şekilde hesaplanmaktadır. Böylece $i=1, \ldots, p$ ve $j=1, \ldots, p$ olduğundan $i=j$ ise $a_{i}^{\prime} a_{j}=1$ ve $i \neq j a_{i}^{\prime} a_{j}=0$ 'dır. $X$ veri matrisinden hesaplanan kovaryans matrisi $S$ ise $Y_{i}^{\prime}$ nin varyansı,

$$
\operatorname{Var}\left(Y_{i}\right)=\operatorname{Var}\left(a_{i}^{\prime} X\right)=a_{i}^{\prime} S a_{i}
$$

şeklinde hesaplanmaktadır [5].

Eşitlik (1)'de görüldüğü gibi $p$ sayıda değişken, yine birbirinden bağımsız $p$ tane temel bileșenle temsil edilmekte yani her bileșene her değișkenin katkı sağladığı görülmektedir. Bu temel bileșenlerin toplam varyansa olan katkıları sıralarına göre artmaktadır. Yani ilk bileşen toplam varyansta yüksek bir açıklama gücüne sahipken ikinci bileșen, buna göre ikinci en yüksek açılklama gücüne sahiptir. Böylece $p$ değeri arttıkça bileşenin açılama gücü bir önceki bileşene göre azalmakta ve son bileşenin toplam varyans içindeki payı göz ardı edilecek kadar azalmaktadır. Özdeğerlerinin büyüklük sırası izlenerek önem sırasına göre hesaplanan temel bileşenler ortogonal ve bu yüzden birbirinden bağımsızdırlar [18].

Temel bileşen analizinin bir diğer önemli özelliği de temel bileşenler tarafından tanımlanan koordinat sisteminde, orijinal değişkenler yerine temel bileşen değerini ifade eden gerçek yeni $\left(X_{k i}\right)$ değişkenlerin yani skorların göstermesine imkân sağlamasıdır. Buna göre, çizilen grafik orijinal verilerin sıkıştırılmış bir genel görünümünü verir. $i$. temel bileşende bir $k$ örneği skorunun koordinatı $i=1, \ldots, p$ ve $k=1, \ldots, n$ ise,

$$
Y_{i k}=a_{i 1} X_{k 1}+a_{i 2} X_{k 2}+\cdots+a_{i p} X_{k p}
$$

şeklinde hesaplanabilir [19].

PCA'ya ait hesaplamaların yapılması ve grafiklerin çizilmesi için SPSS istatistik paket programı [20] kullanılmıştır. Ayrıca Temel Bileşenler analizinin uygulandığı onyedi değişken Tablo 1'de verilmiştir.

\section{Araştırma Bulgular ve Tartışma}

Tablo 1'de İvesi koyunlarının et kalitesinin değerlendirilmesinde kullanılan onyedi ölçüme ait ortalama, standart sapma ve varyasyon katsayıları verilmiştir. Varyasyon katsayıları $\mathrm{pH}, \mathrm{L}^{*}, \mathrm{a}^{*}$, kuru madde, kül, protein, pişirme randımanı ve sululuk gibi değișkenlerde \%10'dan daha küçük değerlere ve b*, TBARS, kollajen ve yağ gibi değişkenlerde ise \%20'den daha büyük değerlere sahiptir. Ayrıca varyasyon katsayısı hiçbir değişkende \%30'dan daha büyük değildir.

Tablo 2'de et kalite özellikleri arasındaki korelasyon katsayıları verilmiştir. Tablo 2 incelendiğinde çiğ ve pişmiş etlere ait bazı değişkenler arasında istatistik olarak anlamlı korelasyonlar olduğu görülür. Özellikle sululuk ile a* ve gevreklik arasında pozitif ve anlaml korelasyon bulunurken, yine sululuk ile kuru madde, protein ve yutmadan önceki çiğneme sayısı arasında da negatif korelasyon bulunmaktadır. Ayrıca protein ile kuru madde arasında pozitif korelasyon ve protein ile kül, pişirme randımanı ve flavor arasinda da negatif korelasyon anlamlı bulunmasına rağmen $\mathrm{pH}, \mathrm{L}^{*}, \mathrm{~b}^{*}$, TBARS ve WBS) ile hiç bir değișken arasında ise anlamlı bir korelasyon bulunmamiștır.

Tablo 3'te et kalite özellikleri için ilk yedi temel bileşene ait analiz sonuçları verilmiştir. Tablo 3'e göre toplam varyansın yaklaşık olarak \% 26.24'lük bölümü ilk bileșenle, \% 46.91'lik bölümü ilk iki bileşenle ve \% 59.47'lik bölümü ise ilk üç temel bileșenle açıklanabilmektedir. Diğer bir ifadeyle on yedi adet değişkene ait toplam varyansın \% 59.47'lik bölümü üç yeni değişkene (temel bileșene) yoğunlaşmıștır. Toplam varyans oranı \%67'den büyük olduğu takdirde orijinal veriyi açıklamak için $p$ değişken yerine ilk $k$ temel bileşenin kullanılması fazla bilgi kaybına yol açmamaktadır [18]. Bundan dolayı verilen ilk dört temel bileșen (\%68.91) ile eğilim açıklanabilir. Ayrıca özdeğerlerine göre değeri 1 'den büyük olan temel bileşenler "önemli" olarak değerlendirilmektedir [21]. Özdeğerlerine göre önemli görünüp dikkate alınan ilk yedi bileşen toplam varyansın çok büyük bir bölümünü (\%89.96) açıklamaktadır.

Tablo 4'te temel bileșen yükleri ve Șekil 1'de ise ilk iki temel bileşenin et kalite özelliklerine göre çizilen ağırlık düzlemi (loading plot) verilmiştir. Ağırlık düzlemi, her değişken ve her temel bileșen arasındaki korelasyona göre yorumlanır. Buna göre birbirine yakın değişkenler arasında pozitif korelasyon bulunurken $180^{\circ}$ ayrık olan değișkenler arasında negatif korelasyon bulunmaktadır. Ayrıca $90^{\circ}$ ayrık olan değişkenler arasında ise korelasyon bulunmamaktadır yani değișkenler birbirinden bağımsızdır [1]. Buna göre $b^{*}$, TBARS, kollajen, kuru madde, pişirme randımanı ve WBS dışındaki 11 değişken ilk temel bileşene etki etmekte ve özellikle bu 11 değişkenden en önemlilerinin duyusal özelliklerden gevreklik, genel kabul edilebilirlik ve yutmadan önceki çiğneme sayısı oldukları görülmektedir. Şekil 1 incelendiğinde bu değişkenlerin ilk temel bileșenin orijininden uzakta 
oldukları gözlenmektedir. pH, L*, kül, yağ, flavor ve yutmadan önceki çiğneme sayısı pozitif korelasyona sahipken kalan diğer 5 değișkenin ise negatif korelasyona sahip oldukları görülmektedir. İkinci temel bileşen bir fiziksel değişken (pişirme randımanı), iki renk değişkeni (a* ve $\mathrm{b}^{*}$ ), iki duyusal değişken (sululuk ve flavor) ve dört kimyasal değişken (kollajen, kuru madde, kül ve protein) ile tanımlanmaktadır. $\mathrm{Bu}$ değişkenler ikinci temel bileşenin orijininden uzak bir noktada bulunmakta ve PC2 ile kollajen, kuru madde ve protein arasında negatif korelasyon, PC2 ile geriye kalanlar arasında ise pozitif korelasyon olduğu görülmektedir (Şekil 1).
Üçüncü temel bileşen TBARS, iki fiziksel değişken (pH ve Warner-Bratzler Shear) ve iki renk değişkeni (a* ve b*) ile tanımlanmaktadır. Şekil 1'de görüldüğü gibi bu değişkenler ilk iki temel bileșenin orijininin uzağına konumlanmışlardır. Dördüncü temel bileșende renk değişkenleri $L^{*}$ ve $b^{*}$ ile kimyasal değişkenler TBARS ve kollajen yer almaktadır.

Beşinci temel bileșende pişirme randımanı ve WBS gibi fiziksel özellikler ile kimyasal özelliklerden yağ bulunmaktadır. Altıncı temel bileşen pH ile kollajen ve yedinci temel bileșen ise yağ değişkeninden oluşmaktadır.

Tablo 1. Ette bazı kalite özelliklerine ilișkin betimleyici istatistikler

\begin{tabular}{lccc}
\hline & Ortalama & St. Sapma & Varyasyon Katsayısı \\
\hline $\mathrm{pH}$ & 5.58 & 0.11 & 1.98 \\
$\mathrm{~L}^{*}$ & 41.67 & 1.95 & 4.69 \\
$\mathrm{a}^{*}$ & 19.69 & 1.92 & 9.72 \\
$\mathrm{~b}^{*}$ & 5.30 & 1.34 & 25.24 \\
TBARS & 0.43 & 0.12 & 26.82 \\
Kollajen (KOLL) & 1.77 & 0.38 & 21.34 \\
Kurumadde (KM) & 26.35 & 1.01 & 3.81 \\
Kül & 1.05 & 0.09 & 8.56 \\
Protein (PRT) & 21.87 & 1.26 & 5.75 \\
Yağ & 2.86 & 0.84 & 29.28 \\
Pişirme randımanı (\%) (PİRA) & 71.96 & 4.59 & 6.39 \\
Warner-Bratzler Shear (WBS) kg & 5.54 & 0.62 & 11.13 \\
Gevreklik (GEV) & 7.02 & 0.92 & 13.12 \\
Sululuk (SUL) & 6.22 & 0.62 & 9.94 \\
Flavor (FLAV) & 4.43 & 0.57 & 12.87 \\
Genel kabul edilebilirlik (GEKA) & 6.48 & 0.65 & 10.04 \\
Yutmadan önceki çiğneme sayısı (YÖÇS) & 25.72 & 3.42 & 13.28 \\
\hline
\end{tabular}

Tablo 2. Et kalite özellikleri arası Pearson korelasyon katsayıları

\begin{tabular}{|c|c|c|c|c|c|c|c|c|c|c|c|c|c|c|c|c|}
\hline & $\mathrm{pH}$ & L & $\mathrm{a}^{*}$ & $\mathrm{~b}^{*}$ & TBARS & KOLL & KM & KÜL & PRT & YAĞ & PİRA & WBS & GEV & SUL & FLAV & GEKA \\
\hline $\mathrm{L}^{*}$ & 0.21 & & & & & & & & & & & & & & & \\
\hline$a^{*}$ & -0.46 & -0.31 & & & & & & & & & & & & & & \\
\hline$b^{*}$ & -0.04 & 0.46 & 0.39 & & & & & & & & & & & & & \\
\hline TBARS & 0.35 & -0.29 & -0.02 & -0.24 & & & & & & & & & & & & \\
\hline KOLL & -0.17 & 0.16 & -0.25 & -0.33 & -0.18 & & & & & & & & & & & \\
\hline KM & -0.32 & 0.07 & 0.09 & -0.28 & 0.00 & 0.16 & & & & & & & & & & \\
\hline KÜL & 0.42 & 0.31 & -0.35 & 0.15 & 0.18 & -0.08 & -0.38 & & & & & & & & & \\
\hline PRT & -0.27 & -0.08 & 0.02 & -0.20 & -0.13 & 0.23 & $0.65^{* *}$ & $-0.56^{*}$ & & & & & & & & \\
\hline YAĞ & 0.27 & 0.25 & -0.25 & -0.27 & -0.03 & 0.11 & 0.25 & 0.31 & -0.44 & & & & & & & \\
\hline PİRA & -0.25 & -0.12 & 0.19 & 0.34 & 0.19 & -0.34 & $-0.49^{*}$ & 0.35 & $-0.55^{*}$ & -0.12 & & & & & & \\
\hline WBS & 0.29 & 0.09 & -0.43 & -0.09 & 0.21 & 0.17 & -0.06 & -0.06 & -0.02 & 0.17 & 0.09 & & & & & \\
\hline GEV & -0.18 & -0.33 & 0.47 & 0.05 & 0.33 & 0.22 & -0.07 & -0.31 & 0.18 & $-0.50^{*}$ & -0.09 & -0.12 & & & & \\
\hline SUL & 0.09 & -0.17 & $0.54^{*}$ & 0.36 & 0.21 & -0.08 & $-0.50^{*}$ & -0.01 & $-0.48^{*}$ & -0.14 & 0.25 & -0.17 & $0.68^{* *}$ & & & \\
\hline FLAV & 0.10 & 0.04 & -0.04 & 0.16 & 0.05 & $-0.61^{*}$ & -0.34 & $0.63^{*}$ & $-0.60^{*}$ & 0.19 & 0.43 & -0.46 & -0.43 & -0.02 & & \\
\hline GEKA & -0.40 & -0.26 & 0.18 & -0.15 & 0.21 & $0.49^{*}$ & -0.17 & -0.27 & 0.12 & $-0.51^{*}$ & 0.05 & -0.07 & $0.82^{* *}$ & 0.43 & -0.38 & \\
\hline YÖÇS & 0.33 & 0.19 & $-0.50^{*}$ & -0.14 & -0.34 & -0.18 & -0.13 & 0.23 & -0.15 & 0.41 & 0.09 & 0.27 & $-0.84^{* *}$ & $-0.50^{*}$ & 0.22 & $-0.73^{* *}$ \\
\hline
\end{tabular}

* $(\mathrm{P}<0.05),{ }^{* *}(\mathrm{P}<0.01)$

Tablo 3. Illk yedi temel bileșen için (temel bileșen) analizi sonuçları

\begin{tabular}{cccc}
\hline Bileșen & Özdeğer & Açıklanan varyans yüzdesi & Kümülatif varyans \\
\hline 1 & 4.46 & 26.24 & 26.24 \\
2 & 3.51 & 20.67 & 46.91 \\
3 & 2.14 & 12.57 & 59.47 \\
4 & 1.61 & 9.44 & 68.91 \\
5 & 1.28 & 7.54 & 76.46 \\
6 & 1.25 & 7.34 & 83.80 \\
7 & 1.05 & 6.16 & 89.96 \\
\hline
\end{tabular}


Tablo 4. İlk yedi temel bileșene ait katsayılar ve yükleri (loadings)

\begin{tabular}{|c|c|c|c|c|c|c|c|c|c|c|c|c|c|c|}
\hline & PC1 & $\%$ & PC2 & $\%$ & PC3 & $\%$ & PC4 & $\%$ & PC5 & $\%$ & PC6 & $\%$ & PC7 & $\%$ \\
\hline pH & 0.50 & 6.58 & 0.07 & 1.03 & 0.57 & 10.69 & 0.02 & 0.54 & 0.19 & 4.75 & 0.52 & 12.94 & -0.16 & 4.60 \\
\hline * & 0.40 & 5.26 & .13 & 1.91 & -0.1 & 1.88 & 0.75 & 20.27 & 0.256 & 6.40 & 0.12 & 2.99 & -0.13 & 3.74 \\
\hline * & -0.56 & 7.37 & 0.41 & 6.02 & -0.51 & 9.57 & -0.08 & 2.16 & 0.140 & 3.50 & 0.17 & 4.23 & 0.37 & 10.63 \\
\hline $\mathrm{b}^{*}$ & 02 & 0.26 & 0.51 & 7.49 & -0.40 & 7.50 & 0.59 & 15.95 & -0.07 & 1.75 & 0.38 & 9.45 & -0.01 & 0.29 \\
\hline ГВА & .13 & 1.71 & 0.25 & 3.67 & 0.58 & 10.88 & -0.51 & 13.78 & 0.116 & 2.90 & 0.29 & 7.21 & -0.08 & 2.30 \\
\hline & .31 & 4.08 & -0.48 & 7.05 & 0.39 & 7.32 & 0.43 & 11.62 & 0.136 & 3.40 & -0.49 & 12.19 & 0.07 & 2.01 \\
\hline & .17 & 2.24 & -0.71 & 10.43 & .31 & 32 & -0.22 & 5.95 & 0.341 & 8.53 & 0.11 & & & 4.31 \\
\hline & & 8.03 & 0.42 & & 0 . & & & 2.43 & 0.261 & 6.53 & -0.21 & 2 & & 8.33 \\
\hline & .45 & 5.92 & -0.72 & 10.57 & -0.24 & 4.50 & -0.06 & 1.62 & -0.115 & 2.88 & 0.23 & 5.72 & -0.32 & 9.20 \\
\hline ağ & & 7.76 & -0.19 & 2.79 & 0.16 & 3.00 & -0.06 & 1.62 & 0.466 & 11.66 & -0.16 & 3.98 & 0.58 & 16.67 \\
\hline$(.+)$ & & 2.11 & 0.69 & 10.13 & -0.06 & 1.13 & -0.07 & 1.89 & -0.479 & 11.98 & -0.25 & 6.22 & 15 & 4.31 \\
\hline WBS & & 2.37 & -0.27 & 3.96 & 0.57 & 10.69 & 0.15 & 4.05 & -0.514 & 12.86 & 0.24 & 5.97 & 0.32 & 9.20 \\
\hline & -0.89 & 11.71 & 0.26 & 3.82 & 0.28 & 5.25 & 0.05 & 1.35 & 0.136 & 3.40 & 0.11 & 2.74 & -0.04 & 1.15 \\
\hline lu & -0.43 & 5.66 & 0.72 & 10.57 & 0.22 & 4.13 & 0.19 & 5.14 & 0.193 & 4.83 & 0.14 & 3.48 & 0.29 & 8.33 \\
\hline & & 7.50 & 0.58 & 8.52 & -0.28 & 5.25 & -0.29 & 7.84 & 0.196 & 4.90 & -0.21 & 5.22 & -0.25 & 7.18 \\
\hline & & & & 2.20 & & & 0.12 & 3.24 & & 1.25 & -0.36 & 8.96 & -0.16 & 4.60 \\
\hline Yut. önc. çğ. sayısı & 0.82 & 10.79 & -0.25 & 3.67 & -0.07 & 1.31 & -0.02 & 0.54 & -0.339 & 8.48 & -0.03 & 0.75 & 0.11 & 3.16 \\
\hline
\end{tabular}

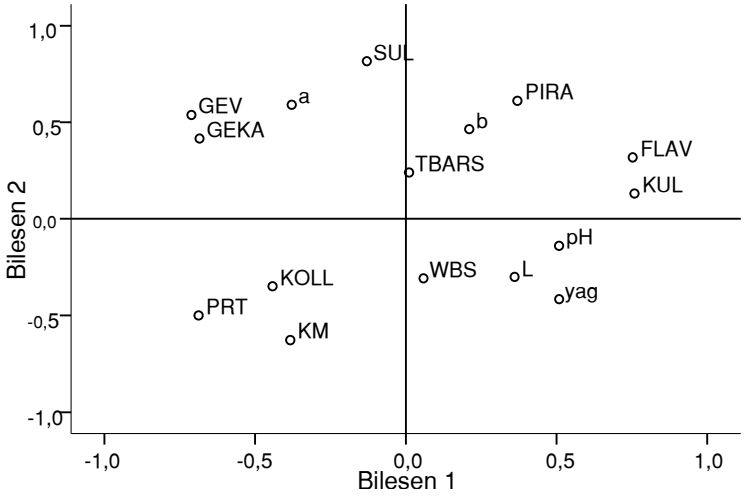

Şekil 1. İlk iki temel bileşen tarafından açıklanan ağırlık düzlemindeki et kalitesi özellikleri

\section{Sonuç}

Et kalitesindeki varyasyon çok fazla değişkene bağlıdır ve her bir değişken ayrı bir öneme sahiptir [10]. Ancak Temel Bileşenler Analizi, incelenen et kalite özelliklerini bağımsız setler halinde gruplandırarak et kalitesinde gözlenen varyansın büyük bir bölümünün renk değerleri, gevreklik, protein ve sululuk ile açlklanabileceğini göstermiştir. Sonuç olarak; diğer istatistik yöntemlerden sağlanan analitik sonuçları vermese bile, Temel Bileşenler analizinin et kalitesinin sübjektif değerlendirilmesinde etkili bir yöntem olarak kullanılabileceği söylenebilir.

\section{Kaynakça}

[1] Kopuzlu, S., Onenc, A., Bilgin, O.C., Esenbuga, N. 2011. Determination of Meat Quality Through Principal Components Analysis. The Journal of Animal \& Plant Science, 21(2), 151-156.

[2] Destafanis, G., Barge, M.T., Brugiapaglia, A., Tassone, S. 2000. The Use of Principal Component Analysis (PCA) to Characterize beef. Meat Science, 56, 255-259.
[3] Pearson, K. 1901. On Lines and Planes of Closest Fit to Systems of Points in Space. Philosophical Magazine, 2, 579-582.

[4] Hotelling, H. 1933. The Most Predictable Criterion. Journal of Educational Psychology., 26, 139-142.

[5] Everitt, S.B., Dunn, G. 2001. Applied Multivariate Data Analysis. Second Ed, John Wiley \& Sons Ltd, London, 335s.

[6] Cañeque, V., Perez, C., Velasco, S., Diaz, M.T., Lauzurica, S., Alvarez, I., Ruiz de Huidobro, F., Onega, E., De la Fuente, J. 2004. Carcass and Meat Quality of Light Lambs Principal Component Analysis. Meat Science, 67, 595-605.

[7] Karlsson, A. 1992. The Use of Principal Component Analysis (PCA) for Evaluation Results from Pig Meat Quality Measurements. Meat Science, 31, 423-433.

[8] Laville, E., Martin, V., Bastien, O. 1996. Prediction of Composition Traits of Young Charolais Bull Carcasses Using a Morphometric Method. Meat Science, 44 (1-2), 93-104.

[9] Hernandez, P., Pla, M., Oliver, M.A., Blasco, A. 2000. Relationships Between Meat Quality Measurements in Rabbits Fed with Three Diets of Different Fat Types and Content. Meat Science, 55, 379-384.

[10] Akçay, A., Yakan, A., Ünal, N. 2014. Bafra (Sakız x Karayaka G1) Kuzularında Et Kalitesinin Değerlendirilmesinde Alternatif bir Yaklaşım: Temel Bileşenler Analizi. Erciyes Üniversitesi Veteriner Fakültesi Dergisi, 11(2), 105-110.

[11] Aurand, L. W., Woods, A. E., Well, M.R. 1987. Food Composition and Analysis. An Avi Book, New York, USA, 690s.

[12] Rödel, W. 1992. Measurement Magnitudes and Transportable Measuring Instruments for in 
Factory Quality Control. Fleischwirtsch, 72(7), 995-1001.

[13] AOAC, 1990. Official Methods of Analysis of the Association of Official Analytical Chemists. 15th ed. Arlington, VA: Association of Analytical Chemists.

[14] Esenbuga, N., Yanar, M., Dayığlu, H. 2001. Physical, Chemical and Organoleptic Properties of Ram Lamb Carcasses from Four Fat-tailed Genotypes. Small Ruminant Research, 39, 99105.

[15] Lemon, D.W. 1975. An improved TBA test for rancidity. New Series Circular No. 51. Halifax Laboratory, Halifax Nova Scotia, Canada.

[16] Kılıç, B., Richards, M.P. 2003. Lipid Oxidation in Poultry Döner Kebap: Pro Oxidative Factors. Journal of Food Science, 68, 688-689.

[17] Tauchmann, F. 1987. Methoden der Chemischen Analytic von Fleisch und Fleischwaren. Bundensanstalt für Fleiscforschung, Klumbach, DE, 80s.

[18] Özdamar, K. 2010. Paket Programlar ile İstatistiksel Veri Analizi-2 (Çok Değişkenli Analizler). 7. Baskı, Kaan Kitapevi, Eskişehir, $506 \mathrm{~s}$.

[19] Bilgin, Ö.C., Önenç, A., Esenbuğa, N. 2004. Sığır Eti Kalitesini Değerlendirmede Temel Bileşenler Analizinin Kullanılması. IV. Ulusal Zootekni Bilim Kongresi, Süleyman Demirel Üniversitesi, 2, 373-378, Isparta.

[20] SPSS Inc. 2004. SPSS Base 13.0 for Windows. Chicago, IL, SPSS Inc.

[21] Alpar, R. 2011. Uygulamalı Çok Değişkenli İstatistiksel Yöntemler. 3. Baskl, Detay Yayıncllı, Ankara, 853s. 